\title{
Jordanian Pre-service EFL Teachers' Perspectives about Phonological Awareness: Contributions to reading development
}

\author{
By Yousef Alshaboul ${ }^{*}$
}

\begin{abstract}
Extant literature confirms a significant relationship between phonological awareness $(P A)$ and the ability to read. Literature in the field provides stimulating evidence that links reading deficits to deficiency in PA. Although reasons behind reading failure may vary and hint towards different factors, a possible assumption relates reading difficulties to the kind and quality of instructions that teachers deliver inside classrooms. This study is aimed to explore the extent of the readiness of pre-service EFL teachers to teach English reading manifest in their beliefs, knowledge, and awareness of PA. Toward this end, a modified questionnaire was distributed to a sample of 158 participants. Reported results show the dominance of traditional teaching beliefs, deficiency in competence, shortage in strategies, and a gap in PA awareness. In conclusion, some recommendations and suggestions are presented.
\end{abstract}

Keywords: EFL, phonological awareness, pre-service teachers, teaching and reading.

\section{Introduction}

Richgels (2001) did not overstate when describing the past few decades as the period of phonological awareness (PA). A growing body of research has confirmed the relationship between PA and a child's ability to read with burgeoning discussions addressing the substantial relationship between the awareness of the sounds of the language and reading. The National Reading Panel's report to the U. S. Congress (2000) recommends exposing children to a rich letter-sound environment in order to develop their reading skills (Snow, Burns, \& Griffin, 1998).

Phonological awareness simply refers to the consciousness of and the ability to manipulate the sounds of the language including syllables, onsets and rimes, and phonemes (Gillet, Temple \& Crawford, 2004; Layton, Deeny, Upton, $\&$ Tall, 1988; 1998; Stanovich, 1994), moving from the stage of sound recognition to sound production (Anthony \& Francis, 2005; Chard \& Dickson, 1999).

Research results on dyslexia back up the aforementioned conclusions by uncovering stimulating evidence linking children reading deficits to deficiency in PA. Some psychologists (Ehri, 1991; Goswami, 2000) noted that children with reading disabilities could neither segment nor blend the sounds of a spoken word. Specialists in the field have confirmed that children with difficulties in detecting or manipulating sounds in words will struggle with learning to read (Anthony \& Farncis, 2005; Hatcher, Hulme, \& Snowling, 2004; Share, 1995;

*Associate Professor, College of Education, The Hashemite University, Jordan. 
Snowling, 1998; Vellutino, Fletcher, Snowling, \& Scanlon, 2004). A plausible contributor to this deficit could be linked to pre-service teachers; the insufficiency in preparing qualified individuals to teaching reading (Newman et al., 2011) especially in PA (National Reading Panel, 2000; Pullen, 2004). Researchers concur on the important role of the PA instruction that early readers receive in the early stages of their literacy development and the power it enjoys in bringing up good readers.

Since children's literacy skills are subject to teachers' instruction, the question most pressing becomes: what are the beliefs, knowledge and practices that preservice teachers of early grades hold about PA in connection with teaching reading? Professionals and parents share a growing concern pointing towards the deterioration in children's reading skills; more children are becoming illiterate. The scattered letters on a white sheet of paper are not for a child but a shattered picture until he manages to break the code and successfully matches those symbols with the corresponding sounds to reach some meaning. Researchers in the field (Adams \& Bruck, 1995; Bos et al., 2001; Juel, 1988) believe that this journey of meaning making should take place early in the life of the child; basic reading skills successfully and early acquired should save children from struggling with words. Researchers (Snow et al., 1998) argue that struggling children during their first to the third year are more likely to stay like that throughout their schooling experience.

According to literature (Adams, 1990; Share \& Stanovich, 1995; Snow et al., 1998), children would have to become better readers experiencing literacy success had they gained command over the alphabets and the phonology of their language. Even in EFL contexts, as Venkatagiri and Levis (2009) suggest, EFL learners should possess the ability to blend, delete, substitute, and identify the sounds within a word or a phrase.

While literature contains evidence showing teachers lack the required and insightful understanding of the basic elements and major concepts involved in the process of teaching reading (Abbott, Walton, \& Greenwood, 2002; Mather, Box, \& Babur., 2001; Troyer \& Yopp, 1990), Al-Hazza and the co-researchers (2008) hope that teachers may recognize the significance of including phonological awareness and language structure in their teaching. Teachers' instructional practices in PA definitely are the by-products of the understanding and knowledge they have about the subject matter (McCutchen et al., 2003). Consequently, the kind of knowledge teachers hold steers the teaching process and affects the level of their reading performance (Ehri \& Williams, 1995; McCutchen et al., 2002). According to McCutchen et al. (2002) and Moats and Foorman (2003), students' performance is found to improve in response to the deep knowledge and effective strategies teachers have power over or the beliefs teachers behold to. Cunningham and her colleagues (2004) argued that teachers' instruction is vulnerable to their perceived level of knowledge and negative perceived beliefs which might result in misrepresentations for phonological content matters leading to a lot of confusion among learners. Therefore, this endeavor took place in order to investigate any possible role for the EFL pre-service teachers in the development of reading. 


\section{Problem of the Study}

Learning English becomes a heavy burden to most Arab EFL learners who seem to have difficulty with prelexical word recognition processes or lexical items when trying to activate semantic, syntactic, and pragmatic associations (Brown \& Hyness, 1985; Fender, 2003; Ryan \& Meara, 1991). The knowledge of these processes is necessary to identify and activate a word or a lexical item (Siedenberg, 1992; Stanovich, 1994; Vellutino, Scanlon, \& Tanzman, 1994), and it is deemed crucial for L2 language reading fluency and comprehension (Eskey, 1988; MacDonald, 2000; Perfetti, 1985).

Based on personal observations and discussions with colleagues teaching English prerequisite classes at a university level, most freshmen lack the basic skills in English literacy. A fair body of those students fails to accurately read one sentence. The Minister of Education announced in December 2013 that early graders face a serious problem in reading; the Ministry of Education is seriously considering adding the kindergarten to make the obligatory years 11 instead of 10 .

When English is taught in classrooms, there is a concern that raises questions about the instruction as a process and the instructors in terms of their beliefs, knowledge, and practices. Are English language teachers competent in reading? Are they ready to teach our children how to read?

English language teachers in Jordan come mainly from the English Language Departments without any substantial preparation in teaching English in the EFL context. English-major graduates leave their departments hardly if so ever ready to teach English. Therefore, it is logical to assume that such teachers lack the necessary knowledge and skills required to develop literacy skills at early graders, in specific, phonological awareness (Tibi, 2005). This paper targeted the pre-service English teachers investigating and comparing their beliefs about, knowledge in, and perceived awareness of PA. This research represents great importance to EFL stakeholders for the impact it may have on the outcome of the teaching-learning process.

\section{Importance of the Study}

Since more than one decade the Ministry of Education in Jordan, following His Majesty King Abdullah II's 1999 National Initiative, has started teaching English simultaneously with Arabic (L1) as a mandatory right from the first grade in order to enable Jordanian first graders to achieve proficiency in English basic skills. The 2006 English Language National Team in Jordan expected first graders to read English and demonstrate understanding when performing tasks and activities. Apparently, those expectations were thwarted in one way or another; the majority of Jordanian children are not fulfilling those goals. Therefore, there is a crucial need to carry out research to investigate reasons behind this failure to help people-in-power make better and more informed decisions to improve the status quo.

This study earns its importance for being, and according to the researchers' 
best knowledge, the first to investigate Jordanian EFL pre-service teachers' beliefs, knowledge and awareness with regard to phonological awareness in the context of instructing early graders to become good readers.

\section{Questions of the Study}

The researchers conducted this study to answer the following questions:

1. What beliefs do prospective EFL teachers hold about PA?

2. Are prospective EFL teachers knowledgeable about PA?

3. Are prospective EFL teachers aware of PA?

\section{Review of Related Literature}

In general, literature supports the key role that phonological skills play in bringing up good readers. Stanovich (1994) heavily counts on the power of phonemic awareness to prudently predict reading achievement even "better than anything else that we know of, including IQ" (p. 284). Whether a child is phonologically aware or not is crucially important since it is the part that most young learners are missing the most (Yopp, 1995), and it is a common consensus in the field that poor phonological awareness greatly contribute to, if not even responsible for, reading failure.

How much do pre-service English language teachers know about PA? Are they knowledgeable enough to teach reading? Are they aware of PA? Ignorance, lack of knowledge, and absence of practice in PA are plausible reasons behind children's poor performance in reading in spite of the command kindergartners may show over vocabulary, syntax, and language sounds (Singer, 1979).

It is important to point out that when referring to teaching in general and how teachers believe learning takes place, it is widespread that teachers almost behold to beliefs they inherited from their past schooling experience where such experience shapes and influences the way they teach when they themselves become teachers (Holt-Reynolds, 1992; Kagan, 1992; Pajares, 1992). Kagan (1992) brings to the attention that pre-service teachers draw on their past experience in order to sort out any new information or knowledge provided to them during training courses. The power of their experience reaches the limit where it channels the new knowledge for their benefit and support rather than to change or challenge their beliefs. While this firmness stance is supported by the work of researchers like Powell (1992), Tatto (1998) and Wubbels (1992), Nettle (1998) confirmed that pre- service teachers' beliefs are stable but some of them are subject to change too. This possibility for change has been supported by Joram and Gabriele (1998), Cabaroglu and Roberts (2000), MacDonald, Badger and White (2001) and others.

Using Johnson's (1996) conceptual and abstract knowledge or Woods' (1996) declarative and procedural, the attainment of the former steers the performance of the latter. In this regard, what Richards and Lockhart (1994) said reflects the 
shared chemistry between the two and depicts the kind of interaction that takes place. Richards and Lockhart explained that "what teachers do is a reflection of what they know and believe" (p. 29). Educators in the field (Cheng et al., 2009) argue that classroom instructions and performance are the by-products of the beliefs that teachers hold.

In the landmark study of Moats (1994), the results regarding 52 licensed teachers' knowledge about oral and written language needed for teaching reading were shocking. Basically, most participants showed great intricacy in demonstrating fundamental skills in reading. Since then, serious research took place looking into knowledge of early reading instruction that pre-service teachers need in order to improve and sharpen their competence and their instructional skills (Brady et al., 2009; Bishop, Brownell, Klingner, Leko, \& Galman, 2010; Kelcey, 2011; Piasta, Connor, Fishman, \& Morrison, 2009; Spear-Swerling, Brucker, \& Alfano, 2005; Spear-Swerling \& Cheesman, 2012; Washburn, Joshi, \& Binks-Cantrell, 2011a; 2011b). This area of research is in need for more studies due to the substantial shortage in studies targeting EFL pre-service readiness to teach reading (Carlisle, Kelcey, Rowan, \& Phelps, 2011).

Finally, another important point is the spread of misconceptions in knowledge and beliefs ranging between the definition of phonological awareness to the actual applications (Cunningham et al., 2004; Moats \& Foorman, 2003). Such misconceptions dominate the pre- and in-service literacy instructors beliefs pertaining to what phonological awareness means (Bos et al., 2001; Moats, 2009; Washburn et al., 2011a, 2011b) in spite of the need for a qualityinstruction to developing reading (Morris, 2011). This is considered very disturbing in the sense that it is vital for pre- and in-service educators to obtain research-based knowledge and develop beliefs accordingly in order to improve the reading abilities and skills of early readers (Moats, 2009). So said, this study is carried out following certain procedures that will help in fulfilling the outlined goals represented in the questions of the study.

\section{Methodology}

\section{Participants}

The participants in this study were EFL undergraduate students majoring in English Language; all of the participants were enrolled in an English Language Program in one of the major universities in the country. The total number of the participants was one hundred and fifty eight pre-service English language teachers. According to their GPA, almost $10 \%$ of the participants $(n=15)$ fell within the 2-2.50 GPA category, around $42 \%$ of the participants $(n=66)$ fell within the $2.51-3$ category, more than $37 \%(n=59)$ participants fell within the 3.1-3.50 category, and the last $11 \%$ of the participants $(n=18)$ fell within the 3.51-4 category. According to their perceived proficiency in English, participants were classified into three levels; low (9.5\%), intermediate (83.5\%) and advanced (7.0\%). 


\section{Tasks and Procedures}

The participants in this study, English pre-service teachers, were asked to fill in a modified version of the Preschool Literacy Practices Checklist (PLPC). The questionnaire requested information in a multiple choice format on background information, including gender, degree and GPA. Furthermore, the questionnaire included items on teachers' knowledge, beliefs and awareness of PA. Participants were asked to identify, locate, and count sounds in words in a multiple choice format, and to indicate the level of agreement to various statements about learning to read and phonemic awareness using a 5-Likert scale.

In details, the instructors monitored the administration of the survey to ensure that surveys were completed individually and to answer any procedural questions that participants might have. For the record, the majority of the participants indicated that the survey was difficult, and several of them felt they did not answer many of the questions correctly. The survey began with questions designed to gather demographic information. The second part was comprised of knowledge calibration questions intended to measure teachers' perceived knowledge of phonological awareness and their beliefs. The final part selected for the purpose of measuring actual knowledge was a phonics pretest published in Self-Paced Phonics: a Text for Educators (Dow \& Baer, 2005). The pretest included questions from three categories of early literacy development; questions related to phonological awareness, phonics, and syllabication. The entire survey took participants approximately thirty to forty minutes to complete.

For reliability purposes, the tool was administered to a group of undergraduate prospective teachers in one of the major universities of the country. A correlation coefficient of 0.84 was considered appropriate, given the purpose of the study. The validity was also checked for through consulting a panel of university professors and teacher experts in the field. All panel recommendations and suggestions were taken seriously.

\section{Results}

Upon running the analysis, the researchers reported the results following the order of the research questions.

\section{Question One: What Beliefs Do Prospective EFL Teachers Hold about PA?}

Table 1. Mean and Standard Deviations for Beliefs about PA

\begin{tabular}{|l|c|c|}
\hline Item (I believe that ...) & Mean & SD \\
\hline $\begin{array}{l}\text { 23. It is important that students compare words and word parts in heard } \\
\text { words. }\end{array}$ & 3.91 & .86 \\
$\begin{array}{l}\text { 24. It is important that students categorize heard words based on sound } \\
\text { patterns. }\end{array}$ & 3.90 & .90 \\
\hline \begin{tabular}{l} 
13. It is important to teach decoding (phonics) strategies. \\
\hline
\end{tabular} & 3.87 & .94 \\
\hline
\end{tabular}


15. It is important to recognize words by sight.

\begin{tabular}{|l|l|}
3.84 & 1.03 \\
\hline
\end{tabular}

\begin{tabular}{|l|l|l|l|}
\hline 5. Individual differences in phonological awareness help explain child's & 3.81 & .88 \\
\hline
\end{tabular} reading growth.

\begin{tabular}{|l|l|l|l|}
\hline 22.It is important that students compare words and word parts in printed & 3.80 & .89
\end{tabular} words

26. It is important that students spend time write letters or words.

3.801 .13

3. Students' ability to recognize letters is a strong predictor of early

reading success.

\begin{tabular}{|l|l|l|}
\hline 2. It is important that students spend time reciting rhymes, songs, or & 3.77 & .82
\end{tabular} poems.

7. The best approach in teaching reading is Whole Language.

\begin{tabular}{l|l|}
3.79 & .94 \\
\hline
\end{tabular}

25. It is important that students categorize printed words based on spelling patterns.

1. Students' ability to rhyme words is a strong predictor of early reading success.

18. Phonics needs to be taught directly to beginning readers to become fluent readers.

4. Poor phonemic awareness inhibits learning to read.

14. Teaching students to decode words is one of my most important goals.

16. It is important to use context to pronounce an unknown word.

21. It is important that students spend time sounding out words

12. It is important that I demonstrate segmenting words into phonemes when reading.

19. It is important that students spend time naming letters.

\begin{tabular}{lll}
3.75 & 1.02 \\
\hline
\end{tabular}

8. The best approach in teaching reading is Phonics

3.75 .91

9. I know how to teach phonological awareness.

11. I know how to teach phonics.

$3.75 \quad .84$

20. It is important that students spend time finding letters in words.

10. I know how to assess phonological awareness.

17. I am a phonics master

$\begin{array}{ll}3.74 & .89\end{array}$

6. Phonemic awareness and phonics mean essentially the same thing

$3.73 \quad .99$

$3.73 \quad .98$

$3.72 \quad 1.09$

$3.70 \quad 1.03$

3.58

3.421 .00

3.411 .02

$3.34 \quad .89$

$3.33 \quad .97$

3.301 .01

$3.28 \quad .86$

$2.87 \quad 1.00$

2.87 .97

The results of the descriptive analysis describing the pre-service students' beliefs about PA (Table1) were not very high; none of the items yielded a mean response of 4.00 (out of 5.00) or higher. Instead, participants' mean responses ranged between 2.87 and 3.91. Participants' relatively higher beliefs were associated with the significance of comparing words and word parts $(\mathrm{M}=3.91$, $\mathrm{SD}=.86)$, categorizing words according to sound patterns $(\mathrm{M}=3.90, \mathrm{SD}=90)$, and focusing on the importance of teaching decoding strategies $(\mathrm{M}=3.87, \mathrm{SD}=$ 94). Participants also held firm beliefs about the importance of helping learners recognize words by sight $(\mathrm{M}=3.84, \mathrm{SD}=1.03)$ taking into account learners' individual differences in $\mathrm{PA}(\mathrm{M}=3.81, \mathrm{SD}=.88)$ as a basis for explaining the variability in their reading growth. On the other hand, the participants' confidence in their mastery of phonics instruction was low $(\mathrm{M}=2.87, \mathrm{SD}=1.00)$, in fact the lowest response, and so was their perceived ability in drawing a line between phonemic awareness and phonics $(\mathrm{M}=2.87, \mathrm{SD}=.97)$. Noticeably, when 
considering the mean responses, the participants held moderate beliefs about other items (e.g., 2, 4, 21, 12, 19, 9, $11 \& 10$ ) despite their crucial role in teaching reading.

\section{Question Two: Are Prospective EFL Teachers Knowledgeable about PA?}

This part of the study was addressed using 24 questions (Table 2) investigating how much participants know about early literacy development; phonological awareness, phonics and syllabication. Participants' mean response on all items addressing this dimension was 9. 34/24.00, $\mathrm{SD}=3.24$, a value that falls below the pass score (12.00), indicating strongly the prospective teachers' incompetence in the area of teaching reading. Looking at them individually, participants' mean responses on the items ranged between $(\mathrm{M}=3, \mathrm{SD}=.18)$ and $(\mathrm{M}=.70, \mathrm{SD}=.58)$. The easiest questions for the participants to answer were those associated with pronouncing certain sounds (e.g., a word with a short vowel sound, a word that has the sound /c/ similar to the initial sound of the word "seal", and pairs of voiceless-voiced consonants). On the other hand, the most difficult items to answer were those related to segmenting and identifying certain sounds in a word (e.g., the second sound in the word "queen", the speech sounds of the word "box", and the combination of two letters representing a single speech sound ).

Table 2. Mean and Standard Deviations of Knowledge about PA

\begin{tabular}{|c|c|c|}
\hline Item (I believe that ...) & Mean & SD \\
\hline $\begin{array}{l}\text { 23. It is important that students compare words and word parts in } \\
\text { heard words. }\end{array}$ & 3.91 & .86 \\
\hline $\begin{array}{l}\text { 24. It is important that students categorize heard words based on } \\
\text { sound patterns. }\end{array}$ & 3.90 & .90 \\
\hline 13. It is important to teach decoding (phonics) strategies. & 3.87 & .94 \\
\hline 15. It is important to recognize words by sight. & 3.84 & 1.03 \\
\hline $\begin{array}{l}\text { 5. Individual differences in phonological awareness help explain } \\
\text { child's reading growth. }\end{array}$ & 3.81 & .88 \\
\hline $\begin{array}{l}\text { 22.It is important that students compare words and word parts in } \\
\text { printed words }\end{array}$ & 3.80 & .89 \\
\hline 26. It is important that students spend time write letters or words. & 3.80 & 1.13 \\
\hline $\begin{array}{l}\text { 3. Students' ability to recognize letters is a strong predictor of early } \\
\text { reading success. }\end{array}$ & 3.79 & .94 \\
\hline $\begin{array}{l}\text { 2. It is important that students spend time reciting rhymes, songs, } \\
\text { or poems. }\end{array}$ & 3.77 & .82 \\
\hline 7. The best approach in teaching reading is Whole Language. & 3.75 & 1.02 \\
\hline $\begin{array}{l}\text { 25. It is important that students categorize printed words based on } \\
\text { spelling patterns. }\end{array}$ & 3.75 & .91 \\
\hline $\begin{array}{l}\text { 1. Students' ability to rhyme words is a strong predictor of early } \\
\text { reading success. }\end{array}$ & 3.75 & .84 \\
\hline $\begin{array}{l}\text { 18. Phonics need to be taught directly to beginning readers to } \\
\text { become fluent readers. }\end{array}$ & 3.74 & .89 \\
\hline 4. Poor phonemic awareness inhibits learning to read. & 3.73 & .99 \\
\hline
\end{tabular}




\begin{tabular}{|l|c|c|}
\hline $\begin{array}{l}\text { 14. Teaching students to decode words is one of my most } \\
\text { important goals. }\end{array}$ & 3.73 & .98 \\
\hline \begin{tabular}{l} 
16. It is important to use context to pronounce an unknown word. \\
\hline 21. It is important that students spend time sounding out words
\end{tabular} & 3.72 & 1.09 \\
\hline $\begin{array}{l}\text { 12. It is important that I demonstrate segmenting words into } \\
\text { phonemes when reading. }\end{array}$ & 3.58 & .98 \\
\hline 19. It is important that students spend time naming letters. & 3.42 & 1.00 \\
\hline 8. The best approach in teaching reading is Phonics. & 3.41 & 1.02 \\
\hline 9. I know how to teach phonological awareness. & 3.34 & .89 \\
\hline 11. I know how to teach phonics. & 3.33 & .97 \\
\hline 20. It is important that students spend time finding letters in words. & 3.30 & 1.01 \\
\hline 10. I know how to assess phonological awareness. & 3.28 & .86 \\
\hline 17. I am a phonics master & 2.87 & 1.00 \\
\hline $\begin{array}{l}\text { 6. Phonemic awareness and phonics mean essentially the same } \\
\text { thing }\end{array}$ & 2.87 & .97 \\
\hline
\end{tabular}

\section{Question Three: Are Prospective EFL Teachers Aware of PA?}

Participants' awareness of PA was elicited using 16 items that addressed their awareness of PA definition, knowledge and capability to teach and assess the four skills of rhyming, segmenting, deletion, and blending. In general, participants' mean responses ranged between $(\mathrm{M}=3.04, \mathrm{SD}=1.14)$ and $(\mathrm{M}=3.34, \mathrm{SD}=2.06)$. The mean response for the participants' awareness was 3.17, standard deviation $=.85$, which can, in general terms, be viewed as intermediate. The participants were more knowledgeable about the importance of rhyming $(\mathrm{M}=3.34, \mathrm{SD}=2.06)$, followed by segmenting $(\mathrm{M}=3.26, \mathrm{SD}=1.34)$. However, they had less awareness concerning how to teach and how to assess PA.

Table 3. Mean and Standard Deviation for Awareness of PA

\begin{tabular}{|l|c|c|}
\hline Items & Mean & Std. Deviation \\
\hline 5. Rhyming is important. & 3.34 & 2.06 \\
\hline 6. Segmenting is important. & 3.26 & 1.34 \\
\hline 3. I know what blending is. & 3.26 & 1.27 \\
\hline 4. I know what deletion is. & 3.23 & 1.34 \\
\hline 2. I know what segmenting is. & 3.22 & 1.22 \\
\hline 12. I know how to teach deletion. & 3.19 & 1.17 \\
\hline 11. I know how to teach blending. & 3.19 & 1.21 \\
\hline 7. Blending is important. & 3.16 & 1.11 \\
\hline 16. I know how to assess deletion. & 3.14 & 1.21 \\
\hline 9. I know how to teach rhyming. & 3.13 & 1.18 \\
\hline 14. I know how to assess segmenting. & 3.11 & 1.11 \\
\hline 8. Deletion is important. & 3.11 & 1.13 \\
\hline 15. I know how to assess blending. & 3.11 & 1.16 \\
\hline 10. I know how to teach segmenting. & 3.09 & 1.13 \\
\hline 1. I know what rhyming is. & 3.09 & 1.25 \\
\hline 13. I know how to assess rhyming. & 3.04 & 1.14 \\
\hline
\end{tabular}




\section{Discussion}

Societies around the globe exert all possible efforts and use all available resources to fight illiteracy; counter efforts aim at spreading literacy among its citizens. Societies do whatever it takes to bring up good readers longing for a future led and dominated by readers. That is why targeting teachers in this study is of great importance for the contribution it may offer in revealing reasons behind the failure youngsters face in reading. Locally speaking, both official and non-official levels, people are getting disappointed by the reading level of their children.

Investigating teachers' beliefs is paramount for its crucial role in steering the teaching process and for its direct impact on students' learning. Based on the results relevant to the first question of the study, it seems that participants failed to yield responses of high means on any of the questionnaire items. Although this is disappointing, it was expected. When looking at the items individually, it could be noticed that the items that yielded the highest mean responses were items that focus on the importance of comparing words and word parts, categorizing them based on sound patterns and teaching decoding. While the attitude toward the first two carries with it positive signals, the third one does not. In specific, the item that focuses on the importance of teaching decoding strategies implies more than what it says. That is, decoding in this part of the world comes first in teachers' instruction; this is the way "word" was introduced to those teachers when in school, and this is how those prospective teachers will introduce the word to their future students in their turn too. This seems very traditional; it is the legacy that generations pass to each other; inherited experience steers and dominate instruction.

What is even worrying is whether those prospective teachers are going to use their past experience as a filter to what to accept and what to reject of the knowledge and experience offered to them in order to help them in running their classes. If that is the case, then whatever training courses are offered to them, chances for change will be slim (Nettle, 1998). It seems their old experience overrules the change. Still, there is a reason for being optimistic; the possibility for change in their stance has been supported by some researchers in the field which means every effort should be made to help such group of prospective teachers to change (Joram \& Gabriele, 1998; Cabaroglu \& Roberts, 2000; MacDonald, Badger, \& White, 2001).

Furthermore, participants failed to yield high responses on items and specific activities that directly relate to developing reading skills like the importance of spending time reciting rhymes, demonstrating how to segment words into phonemes and the importance of spending some time naming letters. In addition, participants failed to yield high-mean responses on items considered crucial for reading instruction; to the contrary, their lowest mean responses were disappointing. Such items were "I know how to teach phonological awareness", "I know how to teach phonics" and "I know how to assess phonological awareness." It is evident that prospective teachers' lowest responses were connected to the methodology and strategies pertinent to teaching and then 
assessing reading. All in all, prospective teachers, it seems, failed to connect such crucially important items to reading. There might be more than one reason responsible for such failure, but thinking of those items in terms of the "new experience" might sound as a logical justification especially in light of the aforementioned argument.

In an attempt to answer the second question of the study, three dimensions were targeted under the knowledge category; phonological awareness, phonics, and syllabication. The participants' mean response on the knowledge test reveals how low their competence is in teaching reading to early-literacy students. This is considered a serious threat for the whole teaching-learning process; if teachers are not as competent as they should be, how then should we expect young children to possess acceptable skills in reading? Allowing those prospective teachers to leave their academic departments without the necessary knowledge is a great disservice not just to themselves but to the whole society at large. There is no doubt that such future teachers will be responsible for the deteriorating situation in reading when it is their turn to run the class. This explains the poor reading skills children have which definitely may severely affect their achievement across the other contents. If students possess poor skills in reading, then this will have adverse consequences on their content learning.

Additionally, those pre-service teachers severely lack the knowledge related to how to teach reading; the basic skills that should be introduced and taught at early stages to learners like segmenting, blending and deleting are the areas that pre-service teachers demonstrated the least experience or knowledge. This could be explained based on two different points. First, the kind of teaching they receive at the university level does not prepare them to be good teachers either because of the courses offered to them or because of the orientations of the departments. In respect of what is said, the departments should take serious efforts in revising and editing their academic degree plans to make sure that their graduates will become good teachers. On the other hand, university instructors should make sure that their syllabi and teaching work hand in hand toward producing competent and ready-to-teach graduates. This will pay off a few years down the road when those departments start receiving fresh students well-instructed in schools before getting into the university level.

Concerning participants' awareness of PA, participants were aware of the importance of the PA more than their awareness of how to teach and assess such skills. It seems participants suffer more with areas related to teaching and assessing than with areas related to content. This result could be interpreted as follows. First, the traditional way of teaching dominates in this part of the world where the focus is on the "What" at the expense of the "How". This explains why learners excel more in content-related activities while they suffer more when it comes to their application. Second, such a status mostly confirms the need for a quality-instruction kind of program that focus on developing the reading abilities and skills vital for early learners (Moats, 2009; Morris, 2011). Still, there is more to do in terms of teacher preparation. 


\section{Conclusion}

This study is aimed at investigating the early-grade teachers' beliefs, knowledge and awareness of phonological awareness and its possible contribution to developing students' reading skills.

To conclude this work, the following understanding emerges. First, there is a notable dominance for the traditional approach over the teaching-learning process with more focus on content rather than on practice. Therefore, efforts should be geared to help teachers change such deeply rooted philosophies and replace them with the state-of-the art strategies. Second, the kind of learning those prospective teachers are exposed to at the university level should be monitored, departments' degree plans should be revised, and courses should be updated. The researcher here can firmly say that there is no one single course in the English departments across the country that prepares future graduates to teach reading. The researcher strongly believes that teacher education programs should offer pre-service teachers explicit instruction in early literacy skills, among which is phonological awareness. While the researcher realizes that comprehension is the overall goal of reading, without an appropriate and accurate instruction in all areas of early literacy, students' comprehension will be inhibited.

This is a call for universities to work diligently on preparing graduates to be up to the tasks and responsibilities awaiting them to manifest in bringing highly literate generations, and this is also a call for decision makers in Higher Education to hold responsible people accountable.

\section{References}

Abbot, M., Walton, C., \& Greenwood, C.R. (2002). Phonemic awareness in kindergarten and first grade. Teaching Exceptional Children, 34(4), 20-26.

Adams, M.J. (1990). Beginning to read: Thinking and learning about print. Cambridge, MA: MIT Press.

Adams, M. J., \& Bruck, M. (1995). Resolving the great debate. American Educator, 19(2), 7-21.

Al-Hazza, T. C., Fleener, Ch., \& Hager, J. (2008). Primary teachers' knowledge and knowledge calibration of early literacy practices. The Reading Matrix, 8(1), 1-11.

Anthony, L., \& Francis, D. (2005). Development of phonological awareness. American Psychological Society, 14(5), 255-258.

Bishop, A.G., Brownell, M.T., Klingner, J.K., Leko, M.M., \& Galman, S.A.C. (2010). Differences in beginning special education teachers: the influence of personal attributes, preparation, and school environment on classroom reading practices. Learning Disability Quarterly, 33, 75-92.

Bos, C., Mather, N., Dickson, S., Podhajski, B., \& Chard, D. (2001). Perceptions and knowledge of pre-service and inservice educators about early reading instruction. Annals of Dyslexia, 51(1), 97-120.

Brady, S., Gillis, M., Smith, T., Lavalette, M., Liss-Bronstein, L., Lowe, E., et al. (2009). First grade teachers' knowledge of phonological awareness and code concepts: examining gains from an intensive form of professional development and corresponding teacher attitudes. Reading and Writing: An International Journal, 
18, 425-455. http://dx.doi.org/10.1007/s11145-009-9166-x.

Brown, T. L. \& Haynes, M. (1985). Literacy background and reading development in a second language. In T.H. Carr (Ed.), The Development of Reading Skills. San Francisco: CA: Jossey-Bass.

Cabaroglu, N., \& Roberts, J. (2000). Development in student teachers' pre-existing beliefs during a 1 year PGCE program. System, 28(3), 387-402.

Carlisle, J.F., Kelcey, B., Rowan, B., \& Phelps, G. (2011). Teachers' knowledge about early reading: effects on students' gains in reading achievement. Journal of Research on Educational Effectiveness, 4, 289-321. http://dx.doi.org/10.1080/19345747. 2010.539297.

Chard, D., \& Dickson, S. (1999). Phonological awareness: Instructional and assessment guidelines. Intervention in School and Clinic, 34, 261-270.

Cheng, M.M.H., Chan, K.W., Tang, S.Y.F., \& Cheng, A.Y.N. (2009). Pre-service teacher education student' epistemological beliefs and their conceptions of teaching. Teaching and Teacher Education, 25, 319-322.

Cunningham, A.E, Perry, K.E., Stanovich, K.E., \& Stanovich, P.J. (2004). Disciplinary knowledge of k-3 teachers and their knowledge calibration in the domain of 10 early literacy. Annals of Dyslexia, 54(1), 139-67.

Dow, R.S., \& Baer, G.T. (2005). Self-Paced Phonics: A Text for Educators. Pearson.

Ehri, L. (1991). Development of the ability to read words. In R. Kamil, P. Mosenthal, \& P. Pearson (Eds.), Handbook of Reading, vol. 2. New York: Longman.

Eskey, D. (1988). Holding in the bottom: An interactive approach to the language problems of second language readers. In P. Carrell, J. Devine, \& D. Eskey (Eds.), Interactive Approaches to Second Language Reading. New York: Cambridge University Press.

Fender M. (2003). English word recognition and word integration skills of native Arabic and Japanese-speaking learners of English as a second language. Applied Psycholinguistics, 24, 289-315.

Gillet, J., Temple, C., \& Crawford, A. (2004). Understanding reading problems: assessment and instruction. Boston: Allyn and Bacon.

Goswami, U. (2000). Phonological representations, reading development and dyslexia: Towards a cross-linguistic theoretical framework. Dyslexia, 6, 133-151.

Hatcher, P., Hulme, C., \& Snowling, M. (2004). Explicit phoneme training combined with reading instructions helps young children at risk of reading failure. Journal of Child Psychology and Psychiatry, 45(2), 338-58.

Holt-Reynolds, D. (1992). Personal history-based beliefs as relevant prior knowledge in course work. American Educational Research Journal, 29(2), 325-49.

Johnson, K.E. (1996). The role of theory in L2 teacher education. TESOL Quarterly, 30(4), 765-771.

Joram E., \& Gabriele, A.J. (1998). Pre-service teacher beliefs: Transforming obstacles into opportunities. Teaching and Teacher Education, 14(2), 175-191.

Juel, C. (1988). Learning to read and write: A longitudinal study of fifty-four children from first through fourth grade. Journal of Educational Psychology, 80, 437-447.

Kagan, S. (1992). Cooperative learning. San Juan Capistrano, CA: Resources for Teachers, Inc.

Kelcey, B. (2011). Assessing the effects of teachers' reading knowledge on students' achievement using multilevel propensity score stratification. Educational Evaluation and Policy Analysis, 33, 458-482. http://dx.doi.org/10.3102/01623 73711415262.

Layton, L., Deeny, K., Upton, G., \& Tall, G. (1988). Researching and promoting phonological awareness in the nursery class. Journal of research in Reading, 19, 113. 
Layton, L., Deeny, K., Upton, G., \& Tall, G. (1998). A pre-school training programme for children with poor phonological awareness: effects on reading and spelling. Journal of Research on Reading, 21(1), 36-52.

Mather, N., Box, C., \& Babur, N. (2001). Perceptions and knowledge of pre-service and inservice teachers about early literacy instruction. Journal of Learning Disabilities, 4, 471-482.

MacDonald, J. (2000). Grammaticality Judgments in a second language: Influences of age of acquisition and native language. Applied Psycholinguistics, 21, 395-423.

MacDonald, M., Badger, R., \& White, G. (2001). Changing values: What use are theories of language learning and teaching? Teaching and Teacher Education, 17, 949-963.

McCutchen, D., Harry, D. R., Cox, S., Sidman, S., Covill, A. E., \& Cunningham, A. E., (2003). Reading teachers' knowledge of children's literature and English phonology. Annals of Dyslexia, 53(1), 23-45.

Moats, L.C. (1994). The missing foundation in teacher education: knowledge of the structure of spoken and written language. Annals of Dyslexia, 44, 81-102. http://dx. doi.org/10.1007/BF02648156.

Moats, L.C. (2009). Knowledge foundations for teaching reading and spelling. Reading and Writing: An International Journal, 22, 379-399. http://dx.doi.org/ 10.1007/s11145-009-9162-1.

Moats, L.C., \& Foorman, B. R. (2003). Measuring teachers' content knowledge of language and reading. Annals of Dyslexia, 53, 23-45.

Morris, D. (2011). Interventions to develop phonological and orthographic systems. In A. McGill-Franzen, \& R. L. Allington (Eds.), Handbook of Reading Disability Research, (pp. 279-288). New York, NY: Routledge.

National Reading Panel. (2000). Teaching children to read: An evidence-based assessment of the scientific research literature on reading and its implications for reading instruction. NIH Publication No. 00-4769. Washington DC: U.S. Government Printing Office.

Nettle E.B. (1998). Stability and change in the beliefs of student teachers during practice teaching. Teaching and Teacher Education, 14(2), 193-204.

Newman, L., Wagner, M., Huang, T., Shaver, D., Knokey, A.-M., \& Yu, J. (2011). Secondary school programs and performance of students with disabilities. A Special Topic Report of Findings from the National Longitudinal Transition Study-2 (NLTS2) (NCSER 2012-3000). U.S. Department of Education. Washington, DC: National Center for Special Education Research. Menlo Park, CA: SRI International. Retrieved from http://bit.ly/2shkR5b.

Pajares, M. F. (1992). Teacher beliefs and educational research: cleaning up a messy construct. Review of Educational Research, 14, 5-19.

Perfetti, C. (1985). Reading ability. New York: Oxford University Press.

Piasta, S.B., Connor, C.M., Fishman, B.J., \& Morrison, F.J. (2009). Teachers' knowledge of literacy concepts, classroom practices, and student reading growth. Scientific Studies of Reading, 224-248. http://dx.doi.org/10.1080/1088843092 851364.

Powell, R. (1992). The influence of prior experience on pedagogical constructs of traditional and nontraditional pre-service teachers. Teaching and Teacher Education, $8(3), 225-238$.

Pullen, P.C. (2004). Effective practices for phonological awareness. Teaching LD HotSheet, 2, Retrieved from http://bit.ly/2rX50vo.

Richards, J. C., \& Lockhart, C. (1994). Reflective teaching in second language classrooms. Cambridge University Press. 
Richgels, D.J. (2001). Invented spelling, phonemic awareness, and reading and writing instruction. In S.B. Neuman \& Dickinson (Eds.), Handbook of early literacy research, 142-55. New York: Guilford.

Ryan, A., \& Meara, P. (1991). The case of the invisible vowels: Arabic speakers reading English words. Reading in a Foreign Language, 7, 531-540.

Share, D. (1995). Phonological recoding and self-teaching: Sine qua non of reading acquisition. Cognition, 55, 151-218.

Share, D. L., \& Stanovich, K. E. (1995). Cognitive processes in early reading development: Accommodating individual differences into aodel of acquisition. Issues in Education: Contributions from Educational Psychology, 1, 1-57.

Siedenberg, M. (1992). Beyond orthographic depth in reading: Equitable division of labor. In R. Frost \& L. Katz (Eds.), Orthography, Phonology, Morphology and Meaning. Amsterdam: North-Holland.

Singer, H. (1979). Language, linguistics, and learning to read. In H. Singer (Ed.), Reading, Learning to Read, pp. 34-41. Victoria, BC: Deakin University.

Snowling, M. (1998). Reading development and its difficulties. Educational and Child Psychology, 15, 44-58.

Snow, C. E., Burns, M. S., \& Griffin, P. (1998). Preventing reading difficulties in young children. Washington, DC: National Academy Press.

Spear-Swerling, L., Brucker, P. O., \& Alfano, M. P. (2005). Teachers' literacy-related knowledge and self-perceptions in relation to preparation and experience. Annals of Dyslexia, 55, 266-296. http://dx.doi.org/10.1007/s11881-005-0014-7.

Spear-Swerling, L., \& Cheesman, E. (2012). Teachers' knowledge base for implementing response-to-intervention models in reading. Reading and Writing: An International Journal, 25, 1691-1723. http://dx.doi.org/10.1007/s11145-0119338-3.

Stanovich, K. (1994). Word recognition: Changing perspectives. In R. Barr, M. Kamil, P. Mosenthal, and P. Pearson (Eds), Handbook of Reading Research, vol. 1. New York: Longman.

Tatto, M.T. (1998). The influence of teacher education on teachers' beliefs about purposes of education, roles and practices. Journal of Teacher Education, 49, 6677.

Tibi, S. (2005). Teachers' Knowledge and Skills in Phonological Awareness in United Arab Emirates. International Journal of Special Education, 20(1), 60-66.

Troyer, S.J., \&Yopp, H.K. (1990). Kindergarten teachers' knowledge of emergent literacy concepts. Reading Improvement, 27, 34-40.

Vellutino, F., Scanlon, D., \& Tanzman, M. (1994). Components of reading ability. In G. Lyon (Ed.), Frames of Reference for the Assessment of Learning Disabilities. Baltimore, MD: Paul H. Brookes.

Vellutino, F., Fletcher, J., Snowling, M., \& Scanlon, D. (2004). Specific reading disability (dyslexia): what have we learned in the past four decades? Journal of Child Psychology and Psychiatry, 45(1), 2-40.

Venkatagiri, H.S., \& Levis, J.M. (2009). Phonological awareness and speech comprehensibility: An exploratory study. Language Awareness, 16(4), 263-277.

Washburn, E.K., Joshi, R.M., \& Binks-Cantrell, E.S. (2011a). Teacher knowledge of basic language concepts and dyslexia. Dyslexia, 17, 165-183. http://dx.doi.org/ $10.1002 /$ dys.426.

Washburn, E. K., Joshi, R. M., \& Binks-Cantrell, E. (2011b). Are pre-service teachers prepared to teach struggling readers? Annals of Dyslexia, 61, 21-43. http://dx. doi.org/10.1007/s11881-010-0040-y.

Woods, D. (1996). Teacher cognition in language teaching. Cambridge: CUP. 
Wubbels, T. (1992). Taking account of student teachers' preconceptions. Teaching and Teacher Education, 8, 137-150.

Yopp, H. (1995). A test for assessing phonemic awareness in young children. The Reading Teacher, 49(1), 516-523. 